\title{
EGFR mutation decreases FDG uptake in non-small cell lung cancer via the NOX4/ROS/GLUT1 axis
}

\author{
LONG CHEN $^{1 *}$, YONGCHUN ZHOU $^{2 *}$, XIAOXIA TANG ${ }^{3 *}$, CONGHUI YANG $^{1 *}$, YADONG TIAN $^{1}$, \\ RAN XIE ${ }^{1}$, TING CHEN $^{4}$, JIAPENG YANG ${ }^{5}$, MINGWEI JING ${ }^{6}$, FUKUN CHEN $^{4}$, \\ CHUN WANG $^{1}$, HUA SUN ${ }^{1}$ and YUNCHAO HUANG ${ }^{2,5}$
}

\begin{abstract}
${ }^{1}$ Department of PET/CT Center, Yunnan Cancer Hospital, The Third Affiliated Hospital of Kunming Medical University, Cancer Center of Yunnan Province; ${ }^{2}$ Tumor Research Institute of Yunnan Province, The Third Affiliated Hospital of Kunming Medical University, Cancer Center of Yunnan Province, Kunming, Yunnan 650118; ${ }^{3}$ Department of Pharmacy, The Second Affiliated Hospital of Kunming Medical University, Kunming, Yunnan 650101; Departments of ${ }^{4}$ Nuclear Medicine, ${ }^{5}$ Thoracic Surgery I and ${ }^{6}$ Ultrasonic, Yunnan Cancer Hospital, The Third Affiliated Hospital of Kunming Medical University, Cancer Center of Yunnan Province, Kunming, Yunnan 650118, P.R. China
\end{abstract}

Received March 19, 2018; Accepted October 8, 2018

DOI: $10.3892 /$ ijo.2018.4626

\begin{abstract}
F}\right]$ fluoro-2-deoxyglucose (FDG) positron emission tomography (PET)-computed tomography (CT) is a functional imaging modality based on glucose metabolism. The association between the maximum standardized uptake value $\left(\mathrm{SUV}_{\max }\right)$ from ${ }^{18}$ F-FDG PET-CT scanning and epidermal growth factor receptor $(E G F R)$ mutation status has, to the best of our knowledge, not previously been fully elucidated, and the potential mechanisms by which EGFR mutations alter FDG uptake are largely unknown. A total of 157 patients who were pathologically diagnosed with non-small cell lung cancer (NSCLC) who underwent EGFR mutation testing and PET-CT pretreatment between June 2015 and October 2017 were retrospectively analyzed. $\chi^{2}$ and univariate analyses were performed to identify
\end{abstract}

Correspondence to: Dr Chun Wang or Dr Hua Sun, Department of PET/CT Center, Yunnan Cancer Hospital, The Third Affiliated Hospital of Kunming Medical University, Cancer Center of Yunnan Province, 519 Kunzhou Road, Kunming, Yunnan 650118, P.R. China E-mail: 13888143457@163.com

E-mail: 649790827@qq.com

*Contributed equally

Abbreviations: ARMS, amplification refractory mutation system; AUC, area under the curve; CT, computed tomography; EGFR, epidermal grow th factor receptor; FDG, [18F]fluoro-2-deoxyglucose; NSCLC, non-small cell lung cancer; PCR, polymerase chain reaction; PET, positron emission tomography; ROC, receiver operating characteristic; $\mathrm{SUV}_{\max }$, maximum standardized uptake value; TKI, tyrosine kinase inhibitor

Key words: epidermal growth factor receptor, non-small cell lung cancer, positron emission tomography-computed tomography, glucose transporter 1, reactive oxygen species, NADPH oxidase 4 the contributors to EGFR mutation. The receiver operating characteristic (ROC) curve was analyzed, and the area under the curve (AUC) was calculated. Glucose transporter 1 (GLUT1) and NADPH oxidase 4 (NOX4) expression, and reactive oxygen species (ROS) activity were detected in the A549 (wild-type), PC-9 (EGFR mutation-positive, EGFR exon 19del) and NCI-H1975 (EGFR mutation-positive, combined with L858R and T790M substitution) cell lines. A total of 109 patients who met the criteria were enrolled, and 63 of those tested as EGFR mutation-positive. The $\mathrm{SUV}_{\max }$ values were significantly lower in patients with EGFR mutations (mean, 6.52 \pm 0.38 ) compared with in patients with wild-type $E G F R$ (mean, 9.37 \pm 0.31 ; $\mathrm{P}<0.001)$. Using univariate analysis, EGFR mutation status was significantly associated with sex, smoking status, tumor histology and $\mathrm{SUV}_{\max }$ of the primary tumor. In the multivariate analysis, smoking status (never-smoking), histopathology (adenocarcinoma) and $\mathrm{SUV}_{\max }(\leq 9.91)$ were the statistically significant predictors of EGFR mutations. ROC curve analysis identified that the $\mathrm{SUV}_{\max }$ cut-off point was 9.92, for which the AUC was 0.75 (95\% confidence interval, 0.68-0.83). Reverse transcription-polymerase chain reaction indicated that the GLUT1 mRNA decreased in the PC-9 and NCI-H1975 cell lines compared with the A549 cell line $(0.82 \pm 0.07$ and $0.72 \pm 0.04$ vs. $0.98 \pm 0.04$, respectively; $\mathrm{P}<0.05)$ and decreased ROS activity was observed in the PC-9 cell line. Furthermore, the expression of NOX4 mRNA decreased by $20 \%$ in PC-9 $(\mathrm{P}<0.01)$ and by $14 \%$ $(\mathrm{P}<0.05)$ in NCI-H1975 cells. In addition, NOX4 protein expression decreased by $13 \%$ in PC-9 and by $16 \%$ in NCI-H1975 cells (both $\mathrm{P}<0.05$ ) compared with the A549 cell line. The SUV $\mathrm{max}_{\max }$ could be considered to effectively predict EGFR mutation status of patients with NSCLC, and the EGFR mutation status may alter FDG uptake partially via the NOX4/ROS/GLUT1 axis.

\section{Introduction}

Globally, lung cancer is the primary contributor to cancer-associated mortality and the leading cause of mortality 
in the majority of regions (1-4). An estimated 222,500 novel lung cancer cases and 155,870 mortalities were predicted to have occurred in 2017 in the USA (1). Of all patients with lung cancer, those with non-small cell lung cancer (NSCLC) account for $\sim 80 \%$ (5). The identification and investigation of genetic drivers such as epidermal growth factor receptor (EGFR)-activating mutations, have contributed to a gradual decrease in lung cancer-associated mortality $(3,6,7)$. EGFR is a member of a larger family of transmembrane receptor tyrosine kinases (TKs) that activate cell proliferation and survival (8). Mutations in the TK domain of EGFR in NSCLC exhibit improved responses to EGFR tyrosine kinase inhibitors (TKIs) such as gefitinib and erlotinib (7), particularly exon 19 deletions and L858R in exon 21.

Previous studies have identified that female Asian patients without a history of smoking and with adenocarcinoma histology are more likely to exhibit EGFR mutations (9). Therefore, validating the EGFR genotype status in patients with NSCLC may help to select those who will benefit from TKIs when making treatment decisions. However, inaccessible tumor sites, insufficient tissues for testing, heterogeneous tumors and a patient's refusal to undergo invasive detection all pose limitations to performing the individual genotype test. Thus, developing non-invasive and effective methods to help with identification of the status of the EGFR gene is required.

$\left[{ }^{18} \mathrm{~F}\right]$ fluorodeoxyglucose (FDG) positron emission tomography (PET)-computed tomography $(\mathrm{CT})$, which is based on high glucose metabolism in lesions, serves an important function in initial staging, evaluating the response following therapy and radiation therapy planning during the management of NSCLC $(10,11)$. Therefore, as a non-invasive method, the quantification of glucose metabolism using FDG-PET is one way to predict EGFR mutations. The standard uptake value maximum $\left(\mathrm{SUV}_{\max }\right)$, a metabolic parameter from PET for FDG uptake, is associated with prognosis in NSCLC and previous studies revealed that patients with NSCLC with a low $\mathrm{SUV}_{\max }$ for the primary lesion tend to have better outcomes $(12,13)$, indicating that a low $\mathrm{SUV}_{\max }$ may be associated with $E G F R$ gene mutations. However, in clinical practice, studies that aim to reveal the FDG uptake and EGFR mutation status are controversial, and the potential mechanisms by which EGFR mutations alter FDG uptake remain largely unknown; therefore, further clinical studies and investigations of the underlying molecular mechanisms should be performed.

Glucose transporter 1 (GLUT1) serves crucial functions in FDG uptake $(14,15)$; furthermore, GLUT1 expression can be altered by dysregulated reactive oxygen species (ROS) activity $(16,17)$, in which NADPH oxidase 4 (NOX4) is primarily responsible for ROS production (18). Considering the aforementioned studies, we hypothesized that EGFR mutations may regulate FDG uptake via the NOX4/ROS/GLUT1 axis in NSCLC.

In the present study, the association between EGFR mutations and $\mathrm{SUV}_{\max }$ was investigated, the receiver operating characteristic (ROC) curve was analyzed to identify the optimum cut-off value for $\mathrm{SUV}_{\max }$ in predicting $E G F R$ mutation, GLUT1 expression and ROS activity were determined in the A549 and PC-9 (EGFR mutation, 19del) cell lines, and NOX4 mRNA and protein expression were investigated to test the hypothesis. Subjects were recruited and enrolled in the present study, and subjected to a battery of tests that included FDG-PET-CT scanning and EGFR mutation testing. The study flow chart is presented in Fig. 1.

\section{Materials and methods}

Patients and diagnosis. In total, 157 patients (median age 65.8 years; range, $48-81$ years) with NSCLC who were diagnosed at the Department of Pathology of The Third Affiliated Hospital of Kunming Medical University (Kunming, China) from June 2015 to October 2017 were enrolled in the present study. All patients fulfilled the following entry criteria: i) The diagnosis was made histologically, and the patients underwent EGFR gene testing; ii) PET-CT was performed prior to any therapy; iii) complete clinical information was obtained; iv) histopathology was reviewed at Yunnan Cancer Hospital (Yunnan, China); and v) written informed consent was obtained from the patients. The study protocol was approved by the Ethics Committee of The Third Affiliated Hospital of Kunming Medical University. All procedures performed in the present study that involved human participants were with the approval of the Institutional Review Board of The Third Affiliated Hospital of Kunming Medical University and in accordance with the 1964 Declaration of Helsinki and its later amendments or comparable ethical standards.

EGFR mutation analysis. An AmoyDx ${ }^{\circledR}$ EGFR 29 Mutations Detection kit (Amoy Diagnostics Co., Ltd., Xiamen, China) was used to detect the EGFR mutation in DNA extracted from tissue and plasma samples using a Qiagen DNA mini-kit (Qiagen GmbH, Hilden, Germany), according to the manufacturer's protocol. The kit methodology is based on amplification refractory mutation system (ARMS) technology, which was used to detect 29 mutations in exons 18 to 21 of the EGFR gene (19) All ARMS primer pairs (AmoyDx, Super-ARMS, 19 del, forward, 5'-GTTAAAATTCCCGTCGCTATCAAG ACATCT-3', and reverse, 5'-CACAGCAAAGCAGAAACT CACAT-3'; L858R, forward, 5'-GCAGCATGTCAAGATCA CAGATTTTGGGCG-3', and reverse, 5'-GTCAGGAAAATG CTGGCTGACCTAAAG-3'; T790M, forward, 5'-CTCACCT CCACCGTGCARCTCATCAT-3', and reverse, 5'-CAATAT TGTCTTTGTGTTCCCGGACA-3'; G719X, forward, 5'-CTC ACCTCCACCGTGCARCTCATCAT-3', and reverse, 5'-CCG TGCCGAACGCACCGGAGCA-3'; S790I, forward, 5'-AGC GTGGACAACCCCCACCAC-3', and reverse, 5'-CCGTGCC GAACGCACCGGAGCA-3') were used for polymerase chain reaction (PCR), with the following criteria: Concentration of $1 \mathrm{mmol} / \mathrm{l}$, control reaction primers at a concentration of $0.1 \mathrm{mmol} / 1$. PCR was performed with denaturation at $94^{\circ} \mathrm{C}$ for $30 \mathrm{sec}, 30 \mathrm{cycles}$ of $95^{\circ} \mathrm{C}$ for $30 \mathrm{sec}, 55^{\circ} \mathrm{C}$ for $30 \mathrm{sec}$ and $72^{\circ} \mathrm{C}$ for $30 \mathrm{sec}$, and another $72^{\circ} \mathrm{C}$ for $6 \mathrm{~min}$.

Interpretation and image analysis of FDG-PET-CT scans. FDG-PET-CT scan images were acquired in the department of PET-CT Center of Yunnan Cancer Hospital using the syngo. via platform (Siemens Healthineers, Erlangen, Germany) (slice thickness, 3-5 mm). The patients fasted for a minimum of $6 \mathrm{~h}$, an FDG dose of $12 \mathrm{mCi}$ was administered, and the patients were scanned from the skull base to the mid-thigh using multiple bed positions (two or three bed positions; acquisition 


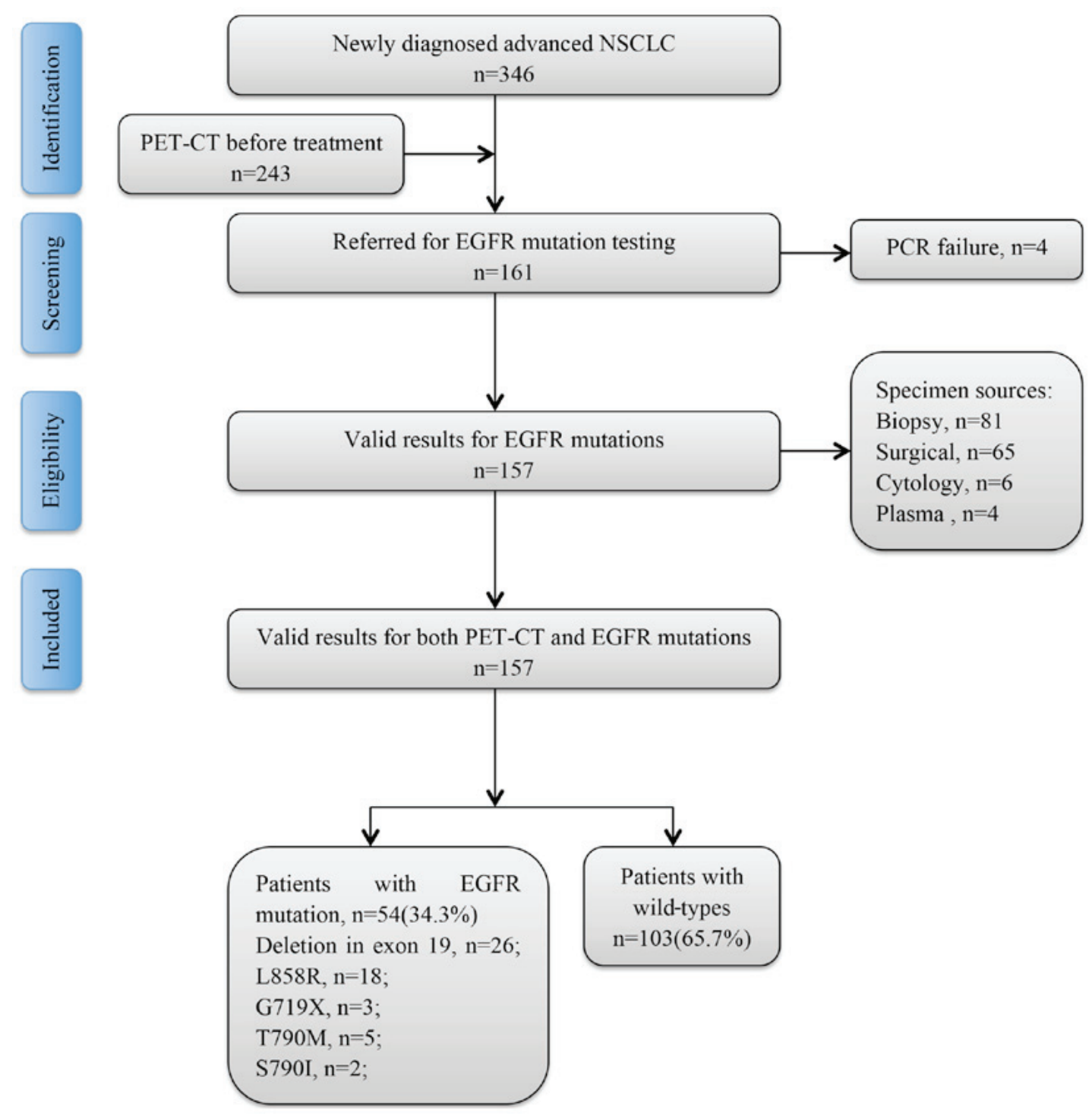

Figure 1. Schematic flow chart of the present study. NSCLC, non-small cell lung cancer; PET, positron emission tomography; CT, computed tomography; $E G F R$, epidermal growth factor receptor; PCR, polymerase chain reaction.

time, $2 \mathrm{~min} /$ bed position) $1 \mathrm{~h}$ after injection. CT-attenuated data were reconstructed using ordered subset expectation maximization for the two scanner sites. Representative images are presented in Fig. 2A and B. The images were reviewed by two board-certified nuclear medicine physicians with 2 and 10 years of experience, respectively. A syngo MultiModality WorkPlace system (Siemens Healthineers) was used to select and measure structures throughout the body using the region-of-interest (ROI) tool within the software. Circular ROIs with a diameter of $10 \mathrm{~mm}$ were drawn on transaxial FDG-PET-CT images using the fusion CT scan as an anatomical guide.

Cell culture. Human NSCLC A549 and NCI-H1975 cells were purchased from the American Type Culture Center (Manassas, VA, USA). PC-9 cells were purchased from RIKEN Cell Bank (Tsukuba, Japan) and is a 19del-positive cell line, whereas A549 is a cell line expressing wild-type EGFR, and the NCI-H1975 cell line harbors the L858R and T790M substitution EGFR mutations. NCI-H1975 and PC-9 cells were grown in RPMI-1640 medium (Thermo Fisher Scientific, Inc., Waltham, MA, USA) supplemented with $10 \%$ fetal bovine serum (FBS; Hyclone; GE Healthcare, Logan, UT, USA), $2 \mathrm{mM}$ L-glutamine and $1 \%$ penicillin/streptomycin. A549 cells were cultured in Dulbecco's modified Eagle's medium (Thermo Fisher Scientific, Inc.) supplemented with 10\% FBS, $2 \mathrm{mM}$ L-glutamine and $1 \%$ penicillin/streptomycin. All cells were maintained and propagated as monolayer cultures at $37^{\circ} \mathrm{C}$ in a humidified $5 \% \mathrm{CO}_{2}$ incubator.

NOX4 mRNA determination. Total RNA was extracted from A549 and PC-9 cells using the TRIzol ${ }^{\circledR}$ reagent (Thermo Fisher Scientific, Inc.), and was reverse-transcribed using a SuperScript II Reverse Transcriptase kit (Takara Biotechnology Co., Ltd., Dalian, China), according to the manufacturer's protocol. Quantitative PCR (qPCR) was performed using a SYBR Green Supermix kit (Takara Biotechnology Co., Ltd.) and the ABI 7300 detection system (Thermo Fisher Scientific, Inc.). Blank controls with no cDNA templates were included to rule out contamination. The specificity of the PCR product 
A
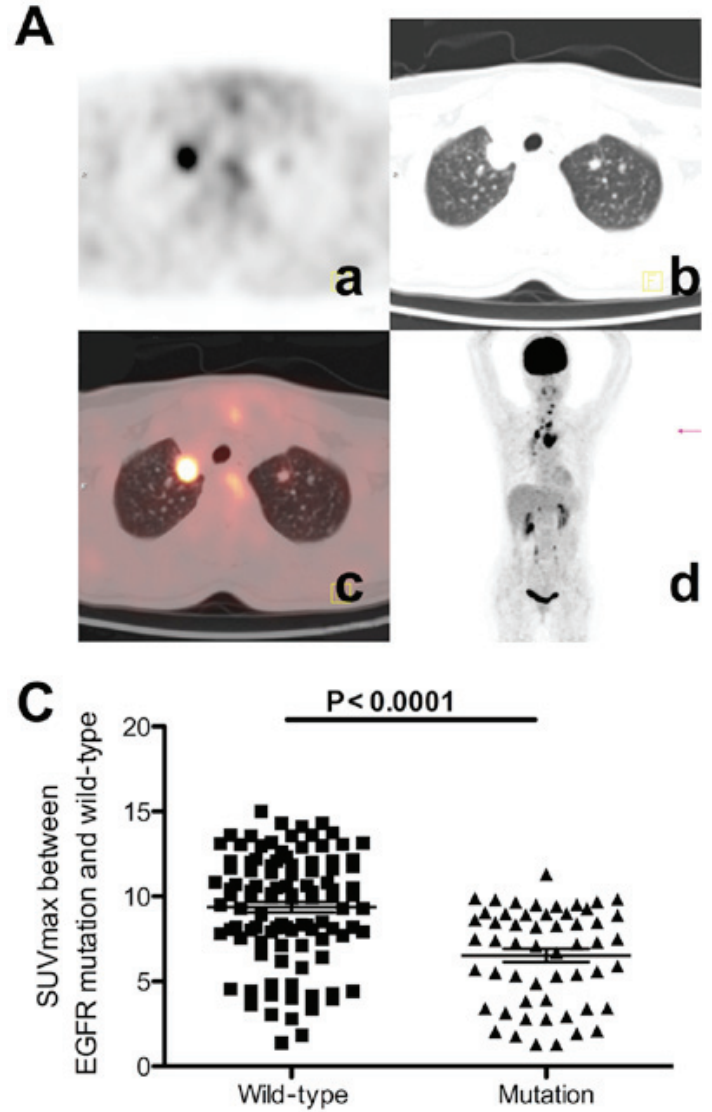

B

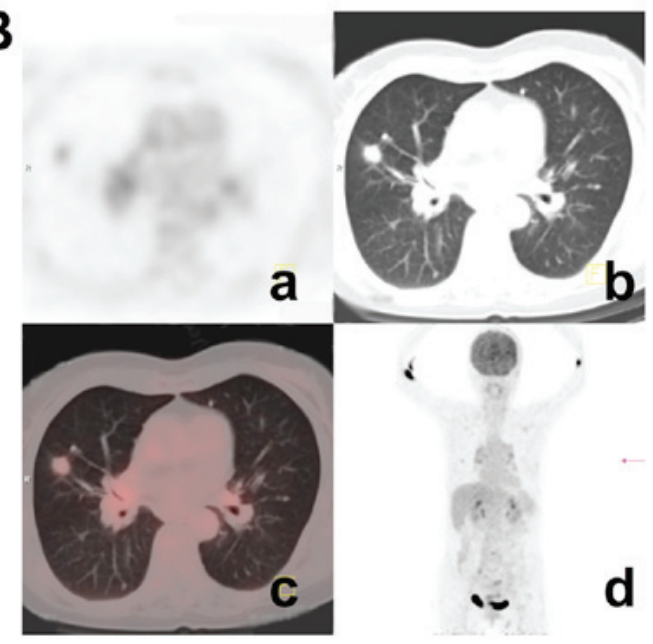

D

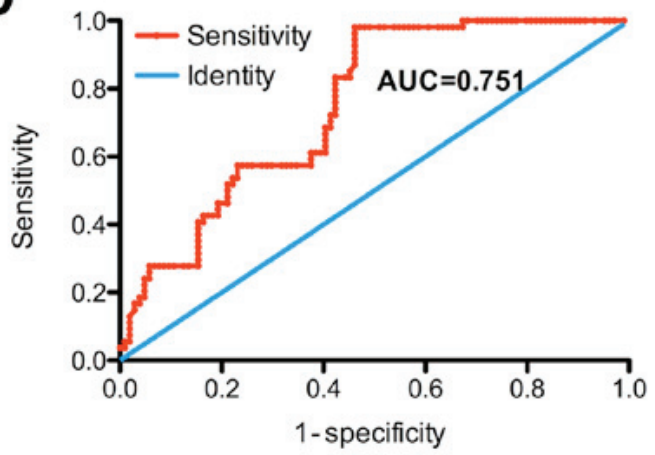

Figure 2. Representative FDG-PET-CT images and $\mathrm{SUV}_{\max }$ values for EGFR mutation and wild-type patients with NSCLC. (A) A 53-year-old man underwent a PET-CT scan to identify a nodule in the upper lobe of the right lung, which was diagnosed pathologically as adenocarcinoma, and EGFR detection revealed no positive mutation. Increased FDG uptake was detected in the lesion, with an $\mathrm{SUV}_{\max }$ of 11.7. (a) PET portion of the PET-CT (transaxial); (b) CT portion of the PET-CT (transaxial); (c) combined PET-CT images (transaxial); (d) MIP. (B) A 64-year-old woman underwent a PET-CT test to identify a mass in the upper lobe of the right lung, which was diagnosed pathologically as adenocarcinoma, and EGFR detection revealed an exon 19 deletion. Slight FDG uptake was observed in the mass, with an $\mathrm{SUV}_{\max }$ of 3.1. (a) PET portion of the PET-CT (transaxial); (b) CT portion of the PET-CT (transaxial); (c) combined PET-CT images (transaxial); (d) MIP. (C) Association between $\mathrm{SUV}_{\max }$ and EGFR mutation status. The $\mathrm{SUV}_{\max }$ was significantly lower in EGFR mutation-positive patients (mean, 6.52 \pm 0.38 ) compared with in wild-type EGFR patients (mean, 9.37 $\pm 0.31 ; \mathrm{P}<0.001$ ). (D) Receiver operating characteristic curve analysis

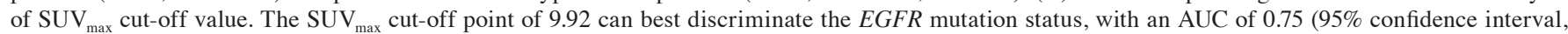
$0.68-0.83$ ). The patients were divided into two groups according to this threshold and it was identified that $E G F R$ mutations were more frequent in patients with a low $\mathrm{SUV}_{\max }(\leq 9.92)$ compared with in patients with a high $\mathrm{SUV}_{\max }(>9.92)(45.3$ vs. $24.4 \%$; $\mathrm{P}=0.007)$. FDG, $\left[{ }^{18} \mathrm{~F}\right]$ fluoro-2-deoxyglucose; PET, positron emission tomography; $\mathrm{CT}$, computer tomography; $\mathrm{SUV}_{\max }$, maximum standardized uptake values; EGFR, epidermal growth factor receptor; NSCLC, non-small cell lung cancer; MIP, maximum intensity projection; AUC, area under the curve.

was confirmed by melting curve analysis and gel electrophoresis. All gene expression levels were normalized to that of the housekeeping gene U6. Relative expression levels of the target gene normalized to U6 were calculated using the $2^{-\Delta \Delta C q}$ method (20). Each reaction was performed independently at least three times. The following primer pairs were used:NOX4 primer set,5'-TGTTGGGCCTAGGATTGTGTT-3' (forward) and 5'-AGGGACCTTCTGTGATCCTCG-3' (reverse); U6 primer set, 5'-CTCGCTTCGGCAGCACA-3' (forward) and 5'-AACGCTTCACGAATTTGCGT-3' (reverse). PCR was performed using the following parameters: $95^{\circ} \mathrm{C}$ for $5 \mathrm{~min}, 30$ cycles of $94^{\circ} \mathrm{C}$ for $30 \mathrm{sec}, 58^{\circ} \mathrm{C}$ for $30 \mathrm{sec}$ and $72^{\circ} \mathrm{C}$ for $30 \mathrm{sec}$, and $72^{\circ} \mathrm{C}$ for $5 \mathrm{~min}$.

Western blot analysis. The cells were solubilized in ice-cold radioimmunoprecipitation assay lysis buffer. Amounts of $25 \mu \mathrm{g}$ protein (determined using a Bicinchoninic Acid Protein assay kit from Abcam, Cambridge, UK) from the cytosolic fraction were separated by SDS-PAGE (10\% gel) and transferred onto a polyvinylidene difluoride membrane. The membrane was incubated with $5 \%$ skimmed milk in Tris-buffered saline containing $0.2 \%$ Tween- 20 at $37^{\circ} \mathrm{C}$ for $2 \mathrm{~h}$. The membrane was then incubated with rabbit anti-NOX4 (cat. no. ab79971; $1: 1,000$ dilution) and mouse anti- $\beta$-actin (cat. no. ab8226; 1:2,000 dilution) primary antibodies (both from Abcam) at room temperature for $2 \mathrm{~h}$. Following washing four times with PBS containing 0.2\% Tween-20 (PBST) each for $10 \mathrm{~min}$, the membrane was incubated with goat anti-rabbit (cat. no. sc-2030; 1:1,500 dilution) and goat anti-mouse (cat. no. sc-2005; 1:2,000 dilution) secondary antibodies (Santa Cruz Biotechnology, Inc., Dallas, TX, USA) at $4^{\circ} \mathrm{C}$ overnight. Following washing four times with PBST each for $10 \mathrm{~min}$, proteins recognized by the antibody were visualized with the Luminata Forte Western Blotting Substrate (EMD Millipore, Billerica, MA, USA), according to the manufacturer's protocol. Image-Pro Plus software (version 6.0) was used to analyze the 
relative protein expression, represented as the density ratio against $\beta$-actin, which was used as an internal reference.

ROS detection. Intracellular ROS levels were determined using the oxidative-sensitive fluorescent probe dihydroethidium (DHE; Molecular Probes; Thermo Fisher Scientific, Inc.), as described previously (21) with certain modifications. Briefly, A549, PC-9 and NCI-H1975 cells $\left(2.5 \times 10^{5}\right)$ in 6-well plates were incubated with $4 \mathrm{M} \mathrm{DHE}$ at $37^{\circ} \mathrm{C}$ for $45 \mathrm{~min}$. The cells were harvested and washed with PBS. The fluorescence from oxidized DHE was detected at a wavelength of $630 \mathrm{~nm}$ and fluorescence images were captured using an Olympus BX51 fluorescence microscope (Olympus Corporation, Tokyo, Japan).

Statistical analysis. Categorical covariates were analyzed using Pearson's $\chi^{2}$ test or Fisher's exact test as appropriate, and continuous covariates were analyzed using Student's t-test or analysis of variance, as appropriate. A ROC curve was generated to determine a cut-off for the $\mathrm{SUV}_{\max }$ of the primary tumor. Multivariate logistic regression analysis was performed to test the variables that yielded predictors of EGFR mutations. The area under the curve (AUC) was used for the predictive value. $\mathrm{P}<0.05$ was considered to indicate a statistically significant difference. GraphPad Prism (version 6.0; GraphPad Software, Inc., La Jolla, CA, USA) was used for the analysis.

\section{Results}

Clinical features and EGFR mutations. The baseline characteristics of the patients are listed in Table I. There were 157 patients (84 males and 73 females) that met the eligibility criteria. Of those, 54 patients (34.3\%) were EGFR mutation-positive. Exon 19 deletion and L858R in exon 21 were the most common mutations, accounting for $48 \%$ (26 patients, including 3 combined mutation types) and $33.3 \%$ (18 patients, all single mutation), respectively. Other mutation types were single G719X (3 patients, 5.5\%), single T790M (5 patients, 9.2\%), single S768I (2 patients, 3.7\%) and combined 19del+T790M (3 patients, 5.5\%). The EGFR mutations were more frequent in female patients compared with in male patients ( 42.3 vs. $26.6 \%$; $\mathrm{P}=0.045)$. The median age was 58.3 years, and 96 patients $(61.1 \%)$ had a history of smoking. EGFR mutations were more frequent in non-smokers compared with in smokers (49.1 vs. $19.1 \%$; $\mathrm{P}=0.006)$. There were 144 patients $(91.7 \%)$ with adenocarcinoma and the remaining 13 patients were without adenocarcinoma $(8.3 \%)$. EGFR mutation status was more frequent in patients with adenocarcinoma compared with patients without adenocarcinoma (36.8 vs. 7.7\%; $\mathrm{P}=0.036)$. In addition, patients harboring EGFR mutations had a lower $\mathrm{SUV}_{\max }$ compared with patients with wild-type EGFR (63 vs. 40\%) (Table I).

Association of $S U V_{\max }$ and EGFR mutations. Using $\chi^{2}$ analysis, the EGFR mutation status was identified to be significantly associated with sex, smoking status, pathological type and the $\mathrm{SUV}_{\max }$ of the primary tumor (Table I). The potential association between $\mathrm{SUV}_{\max }$ and EGFR mutation was investigated, and it was identified that the $\mathrm{SUV}_{\max }$ was significantly lower in patients with EGFR mutations (mean, 6.52 \pm 0.38 ) compared
Table I. EGFR mutation status among various clinical characteristics.

\begin{tabular}{|c|c|c|c|c|}
\hline \multirow[b]{2}{*}{ Clinical characteristic } & \multicolumn{2}{|c|}{$E G F R$ status } & \multirow[b]{2}{*}{$\chi^{2}$} & \multirow[b]{2}{*}{ P-value } \\
\hline & $\begin{array}{l}\text { Mutation } \\
(\mathrm{n}=54)\end{array}$ & $\begin{array}{l}\text { Wild-type } \\
(\mathrm{n}=103)\end{array}$ & & \\
\hline Age, years & & & 0.008 & 1.000 \\
\hline$\leq 60$ & 30 & 58 & & \\
\hline$>60$ & 24 & 45 & & \\
\hline Sex & & & 4.301 & 0.045 \\
\hline Male & 33 & 45 & & \\
\hline Female & 21 & 58 & & \\
\hline Histopathology & & & 4.479 & 0.036 \\
\hline Adenocarcinoma & 53 & 91 & & \\
\hline Non-adenocarcinoma & 1 & 12 & & \\
\hline Diameter, cm & & & 0.006 & 1.000 \\
\hline$\leq 3$ & 25 & 47 & & \\
\hline$>3$ & 29 & 56 & & \\
\hline AJCC stage & & & 1.205 & 0.752 \\
\hline I & 12 & 20 & & \\
\hline II & 12 & 29 & & \\
\hline III & 18 & 28 & & \\
\hline IV & 12 & 26 & & \\
\hline Smoking status & & & 7.568 & 0.006 \\
\hline Ever & 13 & 55 & & \\
\hline Never & 41 & 48 & & \\
\hline Location & & & 0.057 & 0.866 \\
\hline Left & 32 & 59 & & \\
\hline Right & 22 & 44 & & \\
\hline Brain metastasis & & & 0.656 & 0.498 \\
\hline Yes & 21 & 47 & & \\
\hline No & 33 & 56 & & \\
\hline $\mathrm{SUV}_{\max }$ of tumor & & & 42.253 & $<0.001$ \\
\hline$\leq 9.92$ & 53 & 47 & & \\
\hline$>9.92$ & 1 & 56 & & \\
\hline
\end{tabular}

$E G F R$, epidermal growth factor receptor; AJCC, American Joint Committee on Cancer; $\mathrm{SUV}_{\max }$, maximum standardized uptake value.

with that in patients with wild-type EGFR (mean, 9.37 \pm 0.31 ; $\mathrm{P}<0.001$ ) (Fig. 2C). ROC curve analysis revealed an $\mathrm{SUV}_{\max }$ cut-off point of 7.8 (Table I), with an AUC of 0.75 (95\% confidence interval, 0.68-0.83; Fig. 2D). Using $\chi^{2}$ analysis, EGFR mutation status was identified to be significantly associated with sex, smoking status, tumor histopathology and $\mathrm{SUV}_{\max }$ of the primary tumor (Table I). Using multivariate analysis, smoking status (never-smoking), histopathology (adenocarcinoma) and $\mathrm{SUV}_{\max }(\leq 9.91)$ were the statistically significant predictors of EGFR mutations (Table II).

Patients were divided into two groups according to this threshold and it was identified that EGFR mutations were more frequent in patients with a low $\mathrm{SUV}_{\max }(\leq 9.92)$ compared with in patients with a high $\mathrm{SUV}_{\max }(>9.92)$ (53 vs. 1.8\%; $\left.\mathrm{P}<0.001\right)$. 
Table II. Multivariate analysis of potential predictive factors for epidermal growth factor receptor gene mutation.

\begin{tabular}{|c|c|c|c|c|}
\hline Predictive factor & $\begin{array}{c}\text { Univariate analysis } \\
\text { OR }(95 \% \mathrm{CI})\end{array}$ & P-value & $\begin{array}{l}\text { Multivariate analysis } \\
\text { OR }(95 \% \mathrm{CI})\end{array}$ & P-value \\
\hline Age & $0.97 \quad(0.50-1.88)$ & 0.93 & & \\
\hline Sex & $2.03 \quad(1.04-3.96)$ & 0.04 & $1.30(0.55-3.11)$ & 0.55 \\
\hline Histopathology & $6.99 \quad(0.88-55.27)$ & 0.03 & $11.87(1.37-102.86)$ & 0.025 \\
\hline Diameter & $1.03 \quad(0.53-1.99)$ & 0.94 & & \\
\hline AJCC stage & $0.97 \quad(0.63-1.48)$ & 0.75 & & \\
\hline Smoking status & $2.75 \quad(1.32-5.74)$ & 0.006 & $3.31(1.29-8.50)$ & 0.009 \\
\hline Location & $1.09 \quad(0.56-2.12)$ & 0.81 & & \\
\hline Brain metastasis & $0.76 \quad(0.39-1.48)$ & 0.42 & & \\
\hline $\mathrm{SUV}_{\max } \leq 9.92$ & $63.15(8.41-474.14)$ & $<0.001$ & $73.24(9.52-563.63)$ & $<0.001$ \\
\hline
\end{tabular}

OR, odds ratio; CI, confidence interval; AJCC, American Joint Committee on Cancer; $\mathrm{SUV}_{\max }$, maximum standardized uptake value.
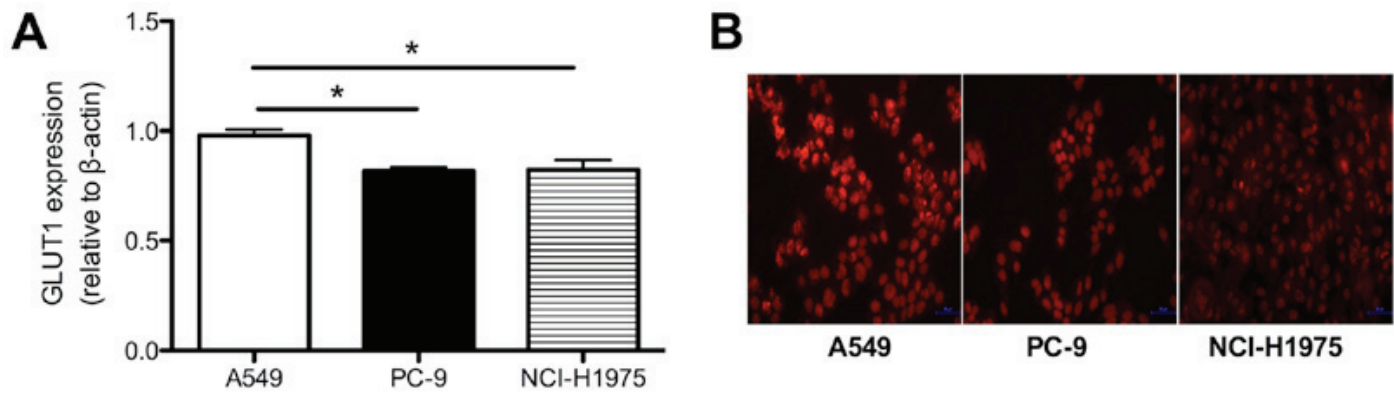
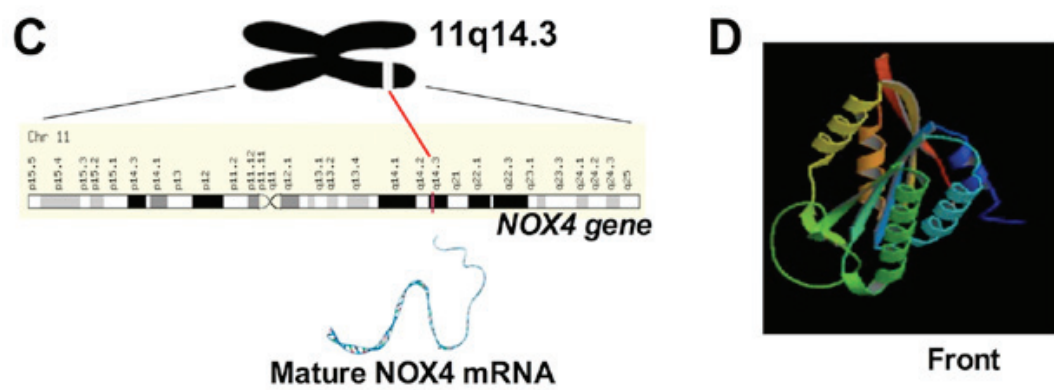

Front

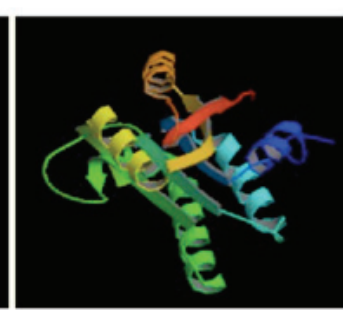

Top

$\mathbf{F}$

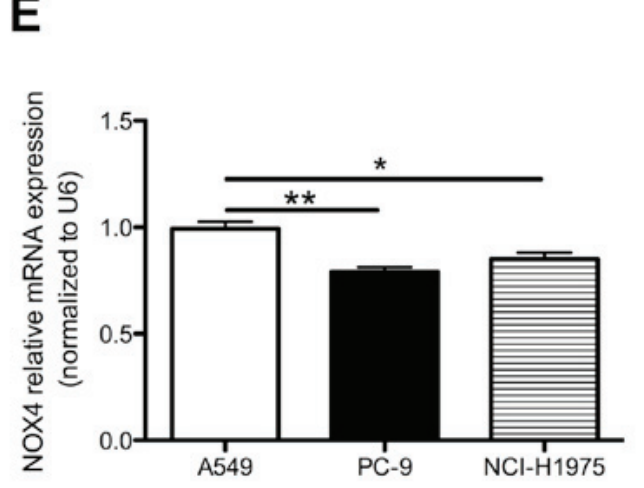

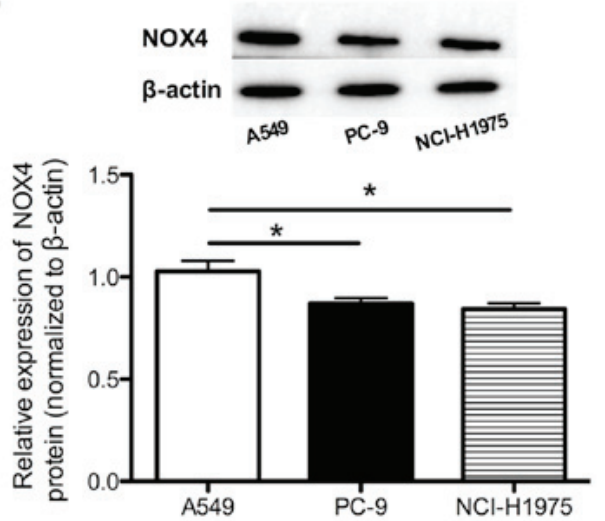

Figure 3. EGFR mutation regulates FDG uptake via the NOX4/ROS/GLUT1 axis. (A) GLUT1 is downregulated in the PC-9 and NCI-H1975 cell lines compared with in the A549 cell line. (B) Decreased ROS activity was detected in the PC-9 and NCI-H1975 cell lines compared with in the A549 cell line. (C) Schematic representation of the NOX4 gene and (D) predicted structure of the NOX4 protein, created using ModBase (49). NOX4 is a gene that maps to the 11q14.3 region and its sequence has been strictly conserved throughout evolution. The NOX4 gene consists of 29 exons, and the NOX4 protein consists of 578 amino acids. This gene encodes a member of the NOX4 family of enzymes that functions as the catalytic subunit of the NADPH oxidase complex. Decreased NOX4 (E) mRNA and (F) protein levels were detected in the PC-9 and NCI-H1975 cell lines compared with in the A549 cell line. The mRNA expression levels of NOX4 decreased by $20 \%$ in PC-9 $(\mathrm{P}<0.01)$ and $14 \%$ in NCI-H1975 $(\mathrm{P}<0.05)$ cell lines, whereas the protein expression decreased by 13 and $16 \%$ in PC-9 and NCI-H1975 cells, respectively (both P<0.05) compared with in the A549 cell line. EGFR, epidermal growth factor receptor; FDG, $\left[{ }^{18} \mathrm{~F}\right]$ fluoro-2-deoxyglucose; NOX4, NAPDH oxidase 4; ROS, reactive oxygen species; GLUT1, glucose transporter 1. 
Table III. Summary of published data on the association between EGFR mutation and $\left[{ }^{18} \mathrm{~F}\right]$ fluoro-2-deoxyglucose uptake.

\begin{tabular}{|c|c|c|c|c|}
\hline Author, year & Primary results & Pathology & $\begin{array}{l}\text { No. of } \\
\text { patients }\end{array}$ & $\begin{array}{l}\mathrm{SUV}_{\max } \text { in } E G F R \\
\text { mutation-positive }\end{array}$ \\
\hline
\end{tabular}

\begin{tabular}{|c|c|c|c|c|c|}
\hline Minamimoto et al, 2017 & $\begin{array}{l}\text { Lower SUV }_{\max } \text { was predictive } \\
\text { for } E G F R \text { mutation }\end{array}$ & $\mathrm{ADC}$ & 131 & $4.2 \pm 3.8$ & $(27)$ \\
\hline Liu et al, 2017 & $\begin{array}{l}\text { No association between } \mathrm{SUV}_{\max } \\
\text { and } E G F R \text { mutation }\end{array}$ & $\begin{array}{l}\text { ADC and } \\
\text { others }\end{array}$ & 87 & Not shown & $(25)$ \\
\hline Takamochi et al, 2017 & $\begin{array}{l}E G F R \text { mutations were more } \\
\text { frequent with lower } \mathrm{SUV}_{\max }\end{array}$ & $\mathrm{ADC}$ & 734 & Median SUV $\mathrm{Sax}_{\operatorname{mas}} 2.7$ & $(28)$ \\
\hline Caicedo et al, 2014 & $\begin{array}{l}\text { No significant differences were } \\
\text { observed in } \mathrm{SUV}_{\max } \text { between } \\
\text { EGFR-positive and wild-type }\end{array}$ & $\mathrm{ADC}$ & 102 & Median $\mathrm{SUV}_{\max }$ was 5.7 & $(29)$ \\
\hline Yoshida et al, 2016 & $\begin{array}{l}\text { Lower levels of } \mathrm{SUV}_{\max } \text { associated } \\
\text { with T790M status }\end{array}$ & $\mathrm{ADC}$ & 34 & $\begin{array}{l}\text { Median } \mathrm{SUV}_{\text {max }} \text { and } \mathrm{SUV}_{\text {mean }} \\
\text { were } 7.26 \text { and } 4.57 \text {, respectively }\end{array}$ & (30) \\
\hline Lee et al, 2015 & $\begin{array}{l}\text { None of the SUV-derived variables } \\
\text { was significantly associated } \\
\text { with } E G F R \text { mutation }\end{array}$ & $\begin{array}{l}\mathrm{ADC} \text { and } \\
\mathrm{SCC}\end{array}$ & 206 & Not shown & (31) \\
\hline Cho et al, 2016 & $\begin{array}{l}\text { Lower } \mathrm{SUV}_{\max } \text { was associated } \\
\text { with } E G F R \text { mutation }\end{array}$ & $\begin{array}{l}\mathrm{ADC} \text { and } \\
\mathrm{SCC}\end{array}$ & 61 & $\begin{array}{l}\mathrm{SUV}_{\max } 9.6 \text { exhibited highest } \\
\text { sensitivity for } E G F R \text { mutation }\end{array}$ & (32) \\
\hline Ko et al, 2014 & $\begin{array}{l}\text { Patients with higher } \mathrm{SUV}_{\max } \\
\text { were more likely to exhibit } \\
E G F R \text { mutations }\end{array}$ & $\mathrm{ADC}$ & 132 & $\mathrm{SUV}_{\max } \geq 6$ & (33) \\
\hline Putora et al, 2013 & $\begin{array}{l}\text { No association between } \\
\mathrm{SUV}_{\max } \text { and } E G F R \text { status }\end{array}$ & $\mathrm{ADC}$ & 28 & $\begin{array}{l}\mathrm{SUV}_{\max } 10.7 \text { vs. } 9.9 \text { in } \\
\text { EGFR-positive and } \\
\text { wild-type, respectively }\end{array}$ & (34) \\
\hline
\end{tabular}

$\mathrm{SUV}_{\text {max }}$, maximum standardized uptake value; EGFR, epidermal growth factor receptor; ADC, adenocarcinoma; SCC, squamous cell carcinoma.

GLUT1 expression is downregulated in EGFR mutated cell lines. Since GLUT1 has been investigated as an important regulator of glucose transport, we hypothesized that the decreased $\mathrm{SUV}_{\text {max }}$ associated with EGFR mutations may be caused by downregulated GLUT1 expression. RT-qPCR revealed that GLUT1 mRNA was decreased in the PC-9 and NCI-H1975 cell lines compared with in the A549 cell line $(0.82 \pm 0.07$ and $0.72 \pm 0.04$ vs. $0.98 \pm 0.04 ; \mathrm{P}<0.05$; Fig. $3 \mathrm{~A}$ ), indicating that decreased GLUT1 may be involved in the downregulated FDG uptake in patients with an EGFR mutated status.

Decreased ROS activity is detected in the PC-9 cell lines. Previous studies have identified that intracellular ROS serve important functions in regulating GLUT1 expression. To determine whether the different GLUT1 expression levels in A549, PC-9 and NCI-H1975 cells are influenced by ROS levels, the intracellular ROS level was determined in A549, PC-9 and NCI-H1975 cells. As presented in Fig. 3B, a marked decrease in the intracellular concentration of ROS was identified in PC-9 and NCI-H1975 cells, which confirmed our hypothesis.

NOX4 mRNA and protein levels are decreased in EGFR-mutated cell lines. NOX4 is a gene that maps to the 11q14.3 region and its sequence has been strictly conserved throughout evolution. The NOX4 gene consists of 29 exons, and the NOX4 protein consists of 578 amino acids. This gene also encodes a member of the NOX4 family of enzymes that functions as the catalytic subunit of the NADPH oxidase complex (Fig. 3C and D). Previous studies have also identified that NOX4 serves crucial functions in $\operatorname{ROS}$ production $(18,22)$. To investigate whether the altered ROS activity was influenced by the NOX4 molecule, mRNA and protein expression levels of NOX4 were determined in the A549, PC-9 and NCI-H1975 cell lines. The NOX4 mRNA was decreased by $20 \%$ in PC-9 $(\mathrm{P}<0.01)$ and by $14 \%$ in NCI-H1975 $(\mathrm{P}<0.05)$ cells, respectively (Fig. 3E), whereas the protein expression decreased by 13 and $16 \%$ in PC-9 and NCI-H1975 cells, respectively (both $\mathrm{P}<0.05$ ), compared with the A549 cell line (Fig. 3F).

\section{Discussion}

In the present study, the association between $\mathrm{SUV}_{\max }$ and $E G F R$ mutation status was investigated in patients with NSCLC. The results revealed that patients who harbored an EGFR mutation exhibited decreased $\mathrm{SUV}_{\max }$ values, and further studies revealed that the EGFR mutation alters the $\mathrm{SUV}_{\max }$ partially via the NOX4/ROS/GLUT1 axis. 


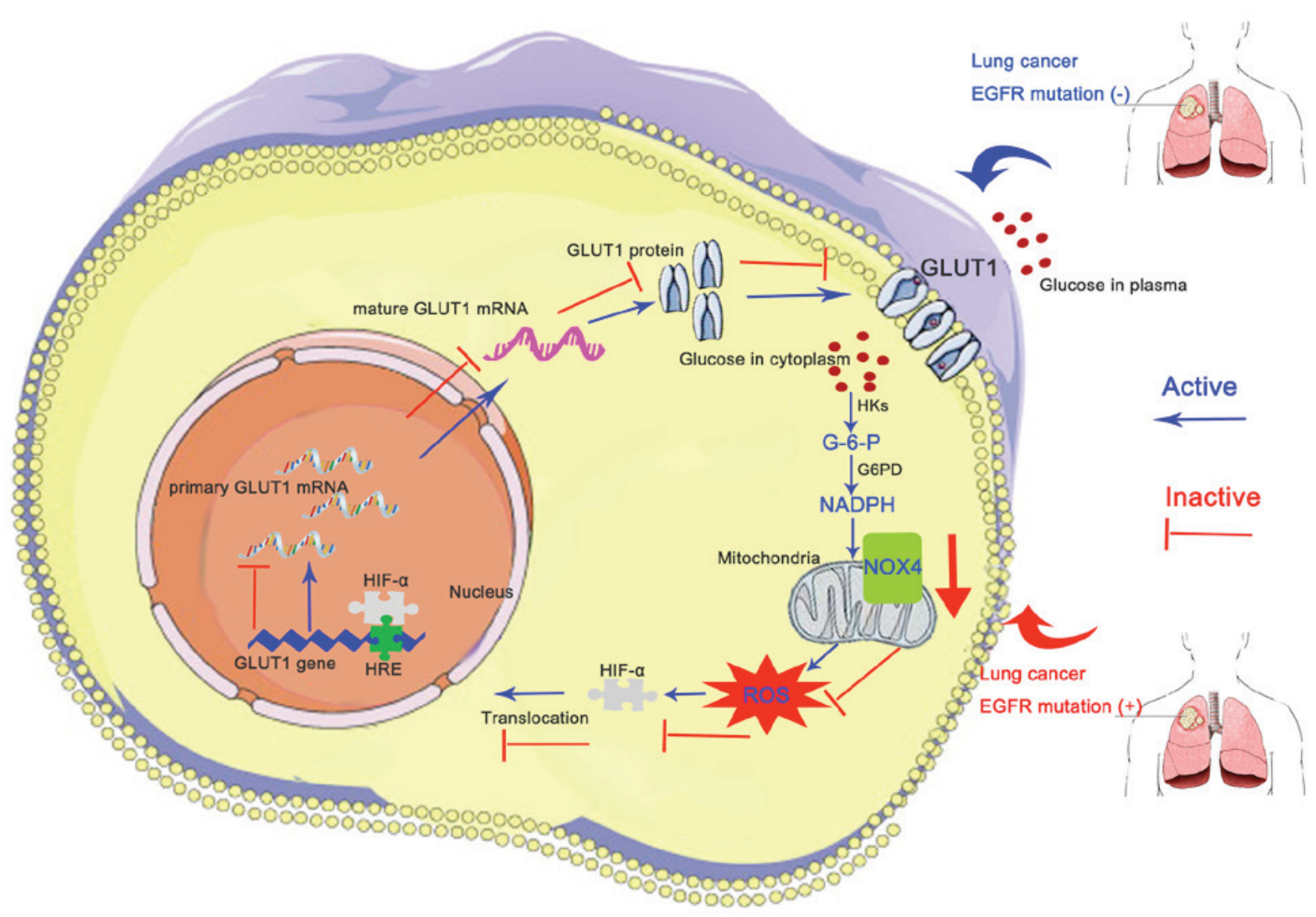

Figure 4. EGFR mutation alters FDG uptake partially via the NOX4/ROS/GLUT1 axis. In patients with EGFR mutation, NOX4 mRNA and protein levels are downregulated, leading to decreased ROS activity, which inhibits HIF- $\alpha$ translocation into the nucleus, resulting in decreased GLUT1 mRNA and protein expression and thereby hindering FDG uptake (decreased maximum standardized uptake value). EGFR, epidermal growth factor; FDG, $\left[{ }^{18}\right.$ F]fluoro-2-deoxyglucose; NOX4, NAPDH oxidase 4; ROS, reactive oxygen species; GLUT1, glucose transporter 1; HIF- $\alpha$, hypoxia-inducible factor $\alpha$; HK, hexose kinase; G-6-P, glucose 6-phosphate; G6PD, glucose-6-phosphate dehydrogenase; HRE, HIF- $\alpha$-response element.

The aims of the present study were as follows: i) To determine whether tumor metabolism can add significant value for predicting $E G F R$ gene mutation; and ii) to investigate the molecular mechanisms by which lung lesions alter the metabolic pathway.

The selection of a suitable therapeutic strategy for a patient suffering from lung cancer is based on the gene status, particularly EGFR. In 2009, Lara-Guerra et al (23) carried out a Phase II study that included 31 patients clinically diagnosed as stage I NSCLC, who received pre-operative gefitinib. The results indicated that tumor shrinkage was frequently seen in women who had never smoked, and the EGFR mutation was the strongest predictor of response. Apart from stage I patients, gefitinib is still useful in patients with stage III/IV NSCLC (3 achieved complete response, 13 exhibited partial response, 3 had stable disease and 2 were discontinued for side effects among the total 21 patients) (24). All these studies indicate the urgent requirement to validate the gene mutation, and a less invasive test method is desirable. Although individual gene detection has been recommended for advanced NSCLC, certain problems (including tumor inaccessibility, insufficient sample tissue for detection and unwillingness to perform invasive detection) have hindered this potential benefit for patients with advanced NSCLC (25). Consequently, a non-invasive strategy for predicting EGFR gene mutation status is advantageous, and the $\mathrm{SUV}_{\max }$, which represents the most active metabolic location within the lesion, has been used as the most convenient metabolic parameter in malignant diseases including lung cancer. However, the association between EGFR mutation and $\mathrm{SUV}_{\max }$ differs markedly among studies, and the data from previous association studies are summarized in Table III. These differences are observed because, first, the $\mathrm{SUV}_{\max }$, a semi-quantitative index, varies with different PET scanners, fasting durations, plasma levels and region of interest parameters, and, secondly, different studies enrolled various sample sizes and disparate pathology types, which may also contribute to variation. A systematic meta-analysis should be performed to evaluate these results (26). The results of the present study indicated that never-smoking, female and lower $\mathrm{SUV}_{\max }$ were the most significant predictive factors for the presence of the EGFR mutation, in accordance with previous studies $(26,27)$. Using a patient's clinicopathological and imaging data, which represents the non-invasive examination, to diagnose EGFR mutation status and other mutations is of marked importance. On the basis of the results of the present study, with an $\mathrm{SUV}_{\max }$ cut-off value of 9.92, the sensitivity and specificity for our prediction model were 98.15 and $53.85 \%$, respectively.

On the basis of the result that decreased FDG uptake was identified in patients harboring an EGFR mutation $(9.37 \pm 0.31$ vs. $6.52 \pm 0.38$, wild-type vs. mutation), the ROC curve was first 
analyzed, and it was identified that the $\mathrm{SUV}_{\max }$ cut-off point was 9.92 and the AUC was 0.75 (95\% confidence interval, 0.68-0.83). Next, we hypothesized that GLUT1, which serves important functions in transporting glucose and is expressed during all stages of embryonic development (35), may function as a key molecule in regulating FDG uptake. Western blotting revealed that GLUT1 decreased markedly in PC-9 and NCI-H1975 cells compared with in A549 cells, indicating that EGFR mutation status may regulate FDG uptake by altering GLUT1 expression. Previous studies have identified that GLUT1 expression may be regulated by ROS in disparate pathways. Under normal conditions, ROS can be produced as a product of normal mitochondrial energy metabolism, and slightly increased ROS functions as a molecular signal to activate various signaling pathways including glucose uptake. However, a persistently high ROS level may reverse the traditional signaling pathway (36). In the present study, the ROS level was determined using DHE and it was revealed that decreased ROS activity was detected in PC-9 and NCI-H1975 cell lines, which is consistent with previous studies. Fiorentini et al (37) identified that decreasing ROS activity by adding the antioxidant EUK-134 downregulated total GLUT1 expression, partially indicating a positive correlation between ROS activity and GLUT1 expression. The dysregulation of the redox balance in cancer cells exerts crucial functions in tumor development and the response to anticancer therapies (38). Kawano et al (39) transfected 293T cells with a vector expressing an Ex19del mutant of human EGFR and identified a marked increase in the intracellular concentration of ROS, indicating a potential association between EGFR mutation and ROS activity. In the present study, ROS activity was also determined, and it was identified that PC-9 cells and NCI-H1975 cells expressed lower ROS levels.

Previous studies have also identified that NOX4 serves crucial functions in ROS production $(18,22)$. NOX4 is a gene that maps to the $11 \mathrm{q} 14.3$ region, and its sequence has been strictly conserved throughout evolution. The NOX4 gene consists of 29 exons, and the NOX4 protein consists of 578 amino acids. This gene encodes a member of the NOX family of enzymes that functions as the catalytic subunit of the NADPH oxidase complex. The encoded protein is localized to non-phagocytic cells where it acts as an oxygen sensor and catalyzes the reduction of molecular oxygen to various ROS. The ROS generated by this protein have been implicated in numerous biological functions including signal transduction, cell differentiation and tumor cell growth $(40,41)$. Furthermore, Prata et al (16) identified that NOX4-derived ROS could maintain a high glucose uptake rate by upregulating GLUT1 in a leukemic cell line (16). In the present study, it was identified that NOX4 mRNA and protein levels were significantly decreased in PC-9 and NCI-H1975 cells, compared with in A549 cells, suggesting an underlying molecular mechanism by which ROS activity is decreased. Previous studies have identified that increased ROS activates hypoxia-inducible factor $\alpha(\mathrm{HIF}-\alpha)$ and bind to HIF- $\alpha$-response elements in the promoter regions of target genes (including GLUT1), thereby increasing GLUT1 mRNA and protein levels $(42,43)$. Conversely, in patients with NSCLC harboring an EGFR mutation, inhibited ROS activity may be responsible for the downregulated GLUT1 protein level (Fig. 4). Indeed, it has been identified previously that NOX4 is essential for EGFR TKI activity. Orcutt et al (44) revealed that the cytotoxicity of erlotinib, an EGFR TKI, was mediated by induction of oxidative stress by inducing the expression of NOX4 in human head and neck cancer. Sobhakumari et al (45) also revealed that erlotinib increased NOX4 mRNA and protein expression by increasing its promoter activity and mRNA stability in FaDu cells, which potentially implied that the primary NOX4 expression is not enough for erlotinib function and the relatively decreased NOX4 expression possibly be a trigger which activates the erlotinib activity.

The limitations of the present study should be clarified. First, the study was designed retrospectively, with a relatively small size (previous studies have ranged in size between 34 and 734 patients). With the accumulation of these small-sample studies, a relatively objective and correct conclusion or opinion may be drawn, for example, by meta-analysis. In addition, a particular geographical issue should be considered. The patient cohort in the present study was primarily from Yunnan Province, an undeveloped, secluded and mountainous province of southwestern China, therefore a number of individuals in this region are unable to afford the relatively expensive cost of PET-CT and gene mutation detection, directly leading to the small sample size. Secondly, a bias could have existed in the process of the patient selection process since the majority of the patients resided in Yunnan Province that is known for high lung cancer rates (46-48). Thirdly, differences in metabolic parameters among different EGFR mutations, and between $E G F R$ mutation and other important mutations (e.g. KRAS) were not discussed, which we intend to address in future studies. In the present study, although direct evidence remains limited, patients with EGFR mutation exhibited obviously decreased $\mathrm{SUV}_{\max }$ compared with those with no EGFR mutation. $\chi^{2}$ analysis revealed that $\mathrm{SUV}_{\max }$ is one predictor of $E G F R$ mutation status and univariate analysis indicated that $\mathrm{SUV}_{\max }$ was the only predictor of EGFR mutation. In the future, with the requisite equipment, FDG uptake among different lung cancer cells with various EGFR mutation status may be detected, which will provide direct evidence. The sample size will be increased and follow-up of patients assessed in the present study will be continued, and it is intended to publish survival results in the future. Finally, it should also be recognized that tissue testing is the gold standard for judging $E G F R$ mutation status.

In conclusion, the results of the present study from clinical samples and cell lines indicate that the FDG uptake was decreased in patients with NSCLC with EGFR mutation. In addition, with a cut-off value of 9.92, the $\mathrm{SUV}_{\max }$ is useful in predicting EGFR mutation, indicating that PET-CT may be a useful non-invasive instrument for predicting EGFR mutation in patients with NSCLC, thereby optimizing the clinical treatment strategy. In addition, further experiments at the cell and molecular levels validated that the NOX4/ROS/GLUT1 axis is responsible for decreased FDG uptake in patients with NSCLC with EGFR mutation, which may reveal potential treatment targets.

\section{Acknowledgements}

Not applicable. 


\section{Funding}

The present study was supported by the Initiation Foundation for Doctors of Yunnan Tumor Hospital (grant no. BSKY201706) and Joint Special Fund from Yunnan Provincial Science and Technology Department-Kunming Medical University for Applied and Basic Research (grant no. 2018FE001-150).

\section{Availability of data and materials}

The datasets used and/or analyzed during the current study are available from the corresponding author on reasonable request.

\section{Authors' contributions}

LC, YZ, XT and CY contributed to the design of the study and wrote the manuscript. YT, RX, TC and JY performed the experiments. MJ, FC, CW, HS and $\mathrm{YH}$ analyzed the data. CW, $\mathrm{HS}$ and $\mathrm{YH}$ also revised and amended the manuscript. All authors have read and approved this manuscript.

\section{Ethics approval and consent to participate}

The study protocol was approved by the Ethics Committee of The Third Affiliated Hospital of Kunming Medical University. All procedures performed in the present study that involved human participants were with the approval of the Institutional Review Board of The Third Affiliated Hospital of Kunming Medical University and in accordance with the 1964 Declaration of Helsinki and its later amendments or comparable ethical standards. Written informed consent was obtained from all patients.

\section{Patient consent for publication}

Written informed consent was obtained from the patients for the publication of this the present paper.

\section{Competing interests}

The authors declare that they have no competing interests.

\section{References}

1. Siegel RL, Miller KD and Jemal A: Cancer Statistics, 2017. CA Cancer J Clin 67: 7-30, 2017.

2. Jung KW, Won YJ, Oh CM, Kong HJ, Lee DH, Lee KH; Community of Population-Based Regional Cancer Registries: Cancer statistics in Korea: Incidence, mortality, survival, and prevalence in 2014. Cancer Res Treat 49: 292-305, 2017.

3. Chen W, Zheng R, Baade PD, Zhang S, Zeng H, Bray F, Jemal A, Yu XQ and He J: Cancer statistics in China, 2015. CA Cancer J Clin 66: 115-132, 2016.

4. Siegel RL, Fedewa SA, Miller KD, Goding-Sauer A, Pinheiro PS, Martinez-Tyson D and Jemal A: Cancer statistics for Hispanics/Latinos, 2015. CA Cancer J Clin 65: 457-480, 2015.

5. Janssen S, Käsmann L, Rudat V and Rades D: Stereotactic body radiation therapy (SBRT) for recurrent non-small cell lung cancer (NSCLC). Anticancer Res 36: 825-828, 2016.

6. Lynch TJ, Bell DW, Sordella R, Gurubhagavatula S, Okimoto RA, Brannigan BW, Harris PL, Haserlat SM, Supko JG, Haluska FG, et al: Activating mutations in the epidermal growth factor receptor underlying responsiveness of non-small-cell lung cancer to gefitinib. N Engl J Med 350: 2129-2139, 2004.
7. Santarpia M, Altavilla G, Salazar MF, Magri I, Pettineo G, Benecchi S and Rosell R: Tyrosine kinase inhibitors for non-small-cell lung cancer: Finding patients who will be responsive. Expert Rev Respir Med 5: 413-424, 2011.

8. Guo G, Gong K, Wohlfeld B, Hatanpaa KJ, Zhao D and Habib AA: Ligand-independent EGFR signaling. Cancer Res 75: 3436-3441, 2015.

9. Sholl LM, Yeap BY, Iafrate AJ, Holmes-Tisch AJ, Chou YP, Wu MT, Goan YG, Su L, Benedettini E, Yu J, et al: Lung adenocarcinoma with EGFR amplification has distinct clinicopathologic and molecular features in never-smokers. Cancer Res 69: 8341-8348, 2009.

10. Kong FM, Ten Haken RK, Schipper M, Frey KA, Hayman J, Gross M, Ramnath N, Hassan KA, Matuszak M, Ritter T, et al: Effect of midtreatment PET/CT-adapted radiation therapy with concurrent chemotherapy in patients with locally advanced non-small-cell lung cancer: A phase 2 clinical trial. JAMA Oncol 3: 1358-1365, 2017.

11. Levine M and Julian J: Imaging: PET-CT imaging in non-small-cell lung cancer. Nat Rev Clin Oncol 6: 619-620, 2009.

12. Na, II, Byun BH, Kang HJ, Cheon GJ, Koh JS, Kim CH, Choe DH, Ryoo BY, Lee JC, Lim SM, et al: ${ }^{18}$ F-fluoro-2-deoxy-glucose uptake predicts clinical outcome in patients with gefitinib-treated non-small cell lung cancer. Clin Cancer Res 14: 2036-2041, 2008.

13. Kobe C, Scheffler M, Holstein A, Zander T, Nogova L, Lammertsma AA, Boellaard R, Neumaier B, Ullrich RT, Dietlein $\mathrm{M}$, et al: Predictive value of early and late residual ${ }^{18} \mathrm{~F}$-fluorodeoxyglucose and ${ }^{18} \mathrm{~F}$-fluorothymidine uptake using different SUV measurements in patients with non-small-cell lung cancer treated with erlotinib. Eur J Nucl Med Mol Imaging 39: 1117-1127, 2012.

14. Horiuchi C, Tsukuda M, Taguchi T, Ishiguro Y, Okudera K and Inoue T: Correlation between FDG-PET findings and GLUT1 expression in salivary gland pleomorphic adenomas. Ann Nucl Med 22: 693-698, 2008.

15. Grabellus F, Nagarajah J, Bockisch A, Schmid KW and Sheu SY: Glucose transporter 1 expression, tumor proliferation, and iodine/glucose uptake in thyroid cancer with emphasis on poorly differentiated thyroid carcinoma. Clin Nucl Med 37: 121-127, 2012.

16. Prata C, Maraldi T, Fiorentini D, Zambonin L, Hakim G and Landi L: Nox-generated ROS modulate glucose uptake in a leukaemic cell line. Free Radic Res 42: 405-414, 2008.

17. Prata C, Maraldi T, Zambonin L, Fiorentini D, Hakim G and Landi L: ROS production and Glut1 activity in two human megakaryocytic cell lines. Biofactors 20: 223-233, 2004.

18. Lo YM: The amplification refractory mutation system. Methods Mol Med 16: 61-69, 1998.

19. Livak KJ and Schmittgen TD: Analysis of relative gene expression data using real-time quantitative PCR and the $2(-\Delta \Delta \mathrm{C}(\mathrm{T}))$ Method. Methods 25: 402-408, 2001.

20. Weyemi U, Lagente-Chevallier O, Boufraqech M, Prenois F, Courtin F, Caillou B, Talbot M, Dardalhon M, Al Ghuzlan A, Bidart JM, et al: ROS-generating NADPH oxidase NOX4 is a critical mediator in oncogenic H-Ras-induced DNA damage and subsequent senescence. Oncogene 31: 1117-1129, 2012.

21. Waris G, Turkson J, Hassanein T and Siddiqui A: Hepatitis C virus (HCV) constitutively activates STAT-3 via oxidative stress: Role of STAT-3 in HCV replication. J Virol 79: 1569-1580, 2005.

22. Kodama R, Kato M, Furuta S, , Ueno S, Zhang Y, Matsuno K, Yabe-Nishimura C, Tanaka E and Kamata T: ROS-generating oxidases Nox1 and Nox4 contribute to oncogenic Ras-induced premature senescence. Genes Cells 18: 32-41, 2013.

23. Lara-Guerra H, Waddell TK, Salvarrey MA, Joshua AM, Chung CT, Paul N, Boerner S, Sakurada A, Ludkovski O, Ma C, et al: Phase II study of preoperative gefitinib in clinical stage I non-small-cell lung cancer. J Clin Oncol 27: 6229-6236, 2009.

24. Sunaga N, Tomizawa Y, Yanagitani N, Iijima H, Kaira K, Shimizu K, Tanaka S, Suga T, Hisada T, Ishizuka T, et al: II prospective study of the efficacy of gefitinib for the treatment of stage III/IV non-small cell lung cancer with EGFR mutations, irrespective of previous chemotherapy. Lung Cancer 56: 383-389, 2007.

25. Liu A, Han A, Zhu H, Ma L, Huang Y, Li M, Jin F, Yang Q and $\mathrm{Yu}$ J: The role of metabolic tumor volume (MTV) measured by $\left[{ }^{18} \mathrm{~F}\right]$ FDG PET/CT in predicting EGFR gene mutation status in non-small cell lung cancer. Oncotarget 8: 33736-33744, 2017.

26. Guan J, Xiao NJ, Chen M, Zhou WL, Zhang YW, Wang S, Dai YM, Li L, Zhang Y, Li QY, et al: ${ }^{18} \mathrm{~F}-\mathrm{FDG}$ uptake for prediction EGFR mutation status in non-small cell lung cancer. Medicine (Baltimore) 95: e4421, 2016. 
27. Minamimoto R, Jamali M, Gevaert O, Echegaray S, Khuong A Hoang CD, Shrager JB, Plevritis SK, Rubin DL, Leung AN, et al: Prediction of EGFR and KRAS mutation in non-small cell lung cancer using quantitative ${ }^{18} \mathrm{~F}$ FDG-PET/CT metrics. Oncotarget 8: 52792-52801, 2017.

28. Takamochi K, Mogushi K, Kawaji H, Imashimizu K, Fukui M, Oh S, Itoh M, Hayashizaki Y, Ko W, Akeboshi M, et al: Correlation of EGFR or KRAS mutation status with ${ }^{18} \mathrm{~F}-\mathrm{FDG}$ uptake on PET-CT scan in lung adenocarcinoma. PLoS One 12: e0175622, 2017.

29. Caicedo C, Garcia-Velloso MJ, Lozano MD, Labiano T, Vigil Diaz C, Lopez-Picazo JM, Gurpide A, Zulueta JJ, Richter Echevarria JA and Perez Gracia JL: Role of ${ }^{18}$ F]FDG PET in prediction of KRAS and EGFR mutation status in patients with advanced non-small-cell lung cancer. Eur J Nucl Med Mol Imaging 41: 2058-2065, 2014.

30. Yoshida T, Tanaka H, Kuroda H, Shimizu J, Horio Y, Sakao Y, Inaba Y, Iwata H, Hida T and Yatabe Y: Standardized uptake value on (18)F-FDG-PET/CT is a predictor of EGFR T790M mutation status in patients with acquired resistance to EGFR-TKIs. Lung Cancer 100: 14-19, 2016.

31. Lee SM, Bae SK, Jung SJ and Kim CK: FDG uptake in non-small cell lung cancer is not an independent predictor of EGFR or KRAS mutation status: A retrospective analysis of 206 patients. Clin Nucl Med 40: 950-958, 2015.

32. Cho A, Hur J, Moon YW, Hong SR, Suh YJ, Kim YJ, Im DJ, Hong YJ, Lee HJ, Kim YJ, et al: Correlation between EGFR gene mutation, cytologic tumor markers, ${ }^{18} \mathrm{~F}$-FDG uptake in non-small cell lung cancer. BMC Cancer 16: 224, 2016.

33. Ko KH, Hsu HH, Huang TW, Gao HW, Shen DH, Chang WC, Hsu YC, Chang TH, Chu CM, Ho CL, et al: Value of ${ }^{18} \mathrm{~F}-\mathrm{FDG}$ uptake on PET/CT and CEA level to predict epidermal growth factor receptor mutations in pulmonary adenocarcinoma. Eur J Nucl Med Mol Imaging 41: 1889-1897, 2014.

34. Putora PM, Früh M and Müller J: FDG-PET SUV-max values do not correlate with epidermal growth factor receptor mutation status in lung adenocarcinoma. Respirology 18: 734-735, 2013.

35. Hogan A, Heyner S, Charron MJ, Copeland NG, Gilbert DJ, Jenkins NA, Thorens B and Schultz GA: Glucose transporter gene expression in early mouse embryos. Development 113 : 363-372, 1991.

36. Liemburg-Apers DC, Willems PH, Koopman WJ and Grefte S: Interactions between mitochondrial reactive oxygen species and cellular glucose metabolism. Arch Toxicol 89: 1209-1226, 2015.

37. Fiorentini D, Prata C, Maraldi T, Zambonin L, Bonsi L, Hakim G and Landi L: Contribution of reactive oxygen species to the regulation of Glut1 in two hemopoietic cell lines differing in cytokine sensitivity. Free Radic Biol Med 37: 1402-1411, 2004.

38. Gorrini C, Harris IS and Mak TW: Modulation of oxidative stress as an anticancer strategy. Nat Rev Drug Discov 12: 931-947, 2013
39. Kawano Y, Iwama E, Tsuchihashi K, Shibahara D, Harada T, Tanaka K, Nagano O, Saya H, Nakanishi Y and Okamoto I: CD44 variant-dependent regulation of redox balance in EGFR mutation-positive non-small cell lung cancer: A target for treatment. Lung Cancer 113: 72-78, 2017.

40. Jafari N, Kim H, Park R, Li L, Jang M, Morris AJ, Park J and Huang C: CRISPR-Cas9 mediated NOX4 knockout inhibits cell proliferation and invasion in HeLa cells. PLoS One 12: e0170327, 2017.

41. Crosas-Molist E, Bertran E, Rodriguez-Hernandez I, Herraiz C, Cantelli G, Fabra À, Sanz-Moreno V and Fabregat I: The NADPH oxidase NOX4 represses epithelial to amoeboid transition and efficient tumour dissemination. Oncogene 36: 3002-3014, 2017.

42. Brunelle JK, Bell EL, Quesada NM, Vercauteren K, Tiranti V, Zeviani M, Scarpulla RC and Chandel NS: Oxygen sensing requires mitochondrial ROS but not oxidative phosphorylation. Cell Metab 1: 409-414, 2005.

43. Jung KH, Lee JH, Thien Quach CH, Paik JY, Oh H, Park JW, Lee EJ, Moon SH and Lee KH: Resveratrol suppresses cancer cell glucose uptake by targeting reactive oxygen species-mediated hypoxia-inducible factor-1alpha activation. J Nucl Med 54: 2161-2167, 2013.

44. Orcutt KP, Parsons AD, Sibenaller ZA, Scarbrough PM, Zhu Y, Sobhakumari A, Wilke WW, Kalen AL, Goswami P, Miller FJ Jr, et al: Erlotinib-mediated inhibition of EGFR signaling induces metabolic oxidative stress through NOX4. Cancer Res 71: 3932-3940, 2011.

45. Sobhakumari A, Schickling BM, Love-Homan L, Raeburn A, Fletcher EV, Case AJ, Domann FE, Miller FJ Jr and Simons AL: NOX4 mediates cytoprotective autophagy induced by the EGFR inhibitor erlotinib in head and neck cancer cells. Toxicol Appl Pharmacol 272: 736-745, 2013.

46. Zhou Y, Yang Y, Yang C, Chen Y, Yang C, Du Y, Zhao G, Guo Y, Ye L and Huang Y: Epidermal growth factor receptor (EGFR) mutations in non-small cell lung cancer (NSCLC) of Yunnan in southwestern China. Oncotarget 8: 15023-15033, 2017.

47. Lan Q, He X, Shen M, Tian L, Liu LZ, Lai H, Chen W, Berndt SI, Hosgood HD, Lee KM, et al: Variation in lung cancer risk by smoky coal subtype in Xuanwei, China. Int J Cancer 123: 2164-2169, 2008.

48. Mumford JL, He XZ, Chapman RS, Cao SR, Harris DB, Li XM, Xian YL, Jiang WZ, Xu CW, Chuang JC, et al: Lung cancer and indoor air pollution in Xuan Wei, China. Science 235: 217-220, 1987.

49. Pieper U, Eswar N, Davis FP, Braberg H, Madhusudhan MS, Rossi A, Marti-Renom M, Karchin R, Webb BM, Eramian D, et al: MODBASE: A database of annotated comparative protein structure models and associated resources. Nucleic Acids Res 34: D291-D295, 2006. 